\title{
Russia and Europe: Between Integration and Diplomacy
}

\section{Is EU-Russia Cooperation a Vital Necessity or a Unique Opportunity?}

\author{
Timofei V. Bordachev
}

\begin{abstract}
Russia and the European Union had all objective preconditions for establishing a lasting cooperative relationship, which could subsequently lead to integration. However, objective factors of their internal development and systemic changes in global politics resulted in a situation where such relations proved to be unclaimed for both parties. The fundamental cause of the crisis in the relations between Russia and Europe was that for both of them the other party
\end{abstract}

Timofei V. Bordachev, Ph.D. (Political Science)

National Research University-Higher School of Economics (HSE), Moscow, Russia,

Faculty of World Economy and International Affairs,

Associate Professor;

Centre for Comprehensive European and International Studies (CCEIS)

Academic Supervisor

SPIN RSCI: 6872-5326

ORCID: 0000-0003-3267-0335

ResearcherID: E-9365-2014

Scopus AuthorID: 56322540000

Tel: $+7(495) 772-9590 * 22186$

E-mail: tbordachev@hse.ru

Address: Office 427, Bldg.1, Malaya Ordynka Str. 17, Moscow 119017, Russia

The paper is partly based on the results of the project "Theoretical and Methodological Aspects in the Analysis of the Development of the EU and Transatlantic Relations" done as part of the HSE Program of Fundamental Studies in 2019. 
was becoming more of an internal negative consolidating factor. In the new historical situation, a return to practices which existed in relations between Russia and Europe before the crisis of 2014 is impossible and, apparently, not viewed as reasonable by either party. However, in the mid-term perspective, the parties may build a new model of relationship based on unbiased assessment of systemic resources and constraints.

Keywords: Russia, the European Union, systemic factors, development, relations, crisis

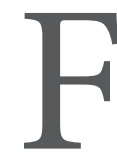

or several centuries, relations between Russia and Europe have been marked by a deep mutual interest and, at the same time, fraught with no less deeply rooted animosity, which sometimes took the form of severe military clashes. However, never in the entire history of their relationship did Russia and Europe have more favorable circumstances for changing this paradigm once and for all than in the last quarter of the 20th century. It was then that objective conditions arose for a rapprochement, not on a metaphysical but on a fully practical and realistic ground, through incorporation of the two parties into a uniform institutionalized system of relations. These conditions, apparent and objective as they were, gave rise to expectations which later proved to be highly overstated.

The failure of this attempt proves the inadequacy of the institutional theory and shows that a larger number of fundamental preconditions should be considered so that the parties could change their behavior, thereby facilitating a transformation of their strategic cultures. Also, consistent internal transformation of Russia and Europe, as well as a change of the international context, may over a longer term bring about conditions in which the factors constraining their integration will cease to be overwhelming. A comprehensive study of all the factors that have a role in the relations between Russia and the EU can significantly improve and enrich the theoretical and methodological toolset of the international cooperation analysis. 
Common experience shows that the more unbridled the initial optimism is, the more apocalyptic sentiments take over if something, everything, or almost everything goes wrong. It is hard to trace a history of international relations similar in scale that would be filled with so many hopes and disappointments as the relations between Russia and Europe. In the second half of the 20th and the beginning of the 21st centuries, it institutionally materialized in the European integration, which in 1991 took the legal form of the European Union. Incidentally, this factor makes it possible to speak of the European Union and use the notion of 'Europe' as an analytical category.

Importantly, the history of relations between Russia and Europe before their contemporary period, which started with Russia's attainment of independence in 1991, was not dramatic, at least in Russia’s perception. Intellectual findings of Russian and Western authors are, undoubtedly, of strong historiographic interest to us, but with all the abundance of relevant literature it boils down to a handful of prominent names, such as de Tocqueville, Karamzin, Khomyakov, Danilevsky, Weber, and Iver Neumann (Neumann, 1996).

Today it is much more important to understand and conceptualize what was the root cause of the failure of the rational attempt to achieve an irreversible strategic rapprochement between Russia and Europe in the unique global and internal, for each of the partners, situation which emerged in the wake of the Cold War. It was then that the parties got a unique chance to shape their relations not within the framework of the traditional diplomatic game, artistically framed by philosophers' and men of letters' reasoning about cultural and spiritual kinship or alienation of Russia and Europe, but on the basis of pragmatic cooperation aimed at creating a new international community (Casier, 2013).

The main hypothesis of this study is that for both Russia and the European Union cooperation and potential integration have always been not a vital necessity critical for attaining major goals of development, but an additional opportunity (which they could use or not use, or else use partially). Correspondingly, the gains expected from cooperation were always regarded as relative benefits for either 
party rather than absolute advantages providing equal benefits for all parties and thus constituting a natural systemic factor.

To prove this hypothesis, historical experience of EU-Russia relations since 1991 to this day has been analyzed with due account for objective systemic factors that determined these relations for each of the parties. Thus, the present study is based on a combination of historical and systemic approaches.

\section{PRESUPPOSITIONS AND ASSUMPTIONS}

At the outset of the 1990s, Europe could come up with a legal framework of cooperation with Russia as it had already amassed vast experience in developing relations not on the basis of situational diplomacy, but on the basis of law and comprehensive binding agreements that made clear the rights and obligations of each participant. In the entire human history, European integration was a unique experiment of creating a community of former enemies on the principles of the non-use of force and resolution of disputes solely through legal framework.

The prerequisites for such fundamental cooperation could be easily identified and substantiated, as is evident from numerous works by Russian and, to a lesser degree, Western authors. The most optimistic of them cast Europe and Russia in the role of close relatives, who, even though sometimes differ in opinion, will find a common language anyway (Roberts, 2007). Knit together by common ground and cultural legacy (which cannot be separated), they just cannot do otherwise-that was the overall tone of the reasoning. Yet the correlation of subjective (geographical closeness and commonality of historical experience) and objective (systemic requirements and constraints) factors remained poorly explored.

At one point, maybe a little belatedly, some Russian authors called for the need for Russia and Europe (EU) to develop a common longterm vision of the future (Kononenko, 2009; Baranovsly, and Utkin, 2012). Similar ideas (for example, Gorbachev's concept of a "Common European Home") had been voiced before, but as speculative suggestions only, without the slightest real grounds. Later, in the early 2000s, everybody understood that such a "home" was impossible, 


\section{Timofei V. Bordachev}

and even the most optimistic Russian authors went no farther than suggesting a "shared vision of the future" (not a "common future"). However, even such, more pragmatic, suggestions faced the fact that for none of the parties such a vision proved necessary within the framework of Realpolitik and the real goals they set for themselves in that specific historical period.

Common strategic vision suggests the ability to picture an equitable relationship. But for Europe this was impossible from the very start. By the end of the 1990s, the concept of a "Europe of concentric circles" took hold, suggesting that the place of each of the partners was determined by its closeness to the EU (but without membership therein). It should be noted that for many in Russia such model was even desirable, although it was not clear what it should be actually like. In any case, Russia's gigantic scope alone could bring to a deadlock any discussion on how to "embed" its natural greatness in an assemblage of EU states, relatively commeasurable in dimension.

Moreover, neither Russia nor the European Union could really view the interests of the other party as part of its own interests. The reason was their qualitative difference as political players and, correspondingly, difference in goal-setting. Russia has always acted as a relatively homogenous player, able to abstract its internal processes from its interests and behavior on the global stage. For the European Union, foreign contacts were a continuation of its domestic development, even to a greater extent than, for instance, for the U.S. today. The system of the EU's external contacts and interests has always been essentially dependent on the dynamics of European integration and, consequently, could not incorporate the interests of a party (Russia) not involved in the integration process.

In the mid-2000s, these basic contradictions were aggravated by increased difference in ideological and value approaches. Up until the outset of the so-called "wave of right-wing populism" (its advocates achieved biggest success in the elections to the European Parliament in 2019), the dominant values in Russia and Europe were becoming ever more divergent, not to say alien. This divergence was initially noted by European authors (Haukkala, 2009; White and Light, 2005) 
and was later studied in earnest by Russian experts (Romanova, 2016). One can even suppose that as the role of value conservatism in Russia grew, Europe itself was increasingly perceived as a "consolidating Other"-not in Neumann's sense of uniting nations, but in the sense of consolidating a nation consisting of various ethnic and religious groups. Thus, Europe, as an adversary, was becoming an essential part of the ideological construct of the new Russian statehood, a 'state-nation.'

And, finally, the key factor which worked against rapprochement of Russia and the European Union was their completely different vision of the security problem, both at the regional and the national levels. The European Union, from the very moment of its emergence as a relatively autonomous entity of the international system, was rid of serious concerns in terms of traditional security. These problems were efficiently dealt with by the North Atlantic Treaty Organization (NATO) and the U.S. as a "benign hegemon." Therefore, from 1991 to 2014 the discussion on cooperation of EU countries in the security field hinged on the problems of peacekeeping missions beyond the bounds of the EU's immediate periphery.

In pursuing its policy in the East-first of enlargement and then of neighborliness - the European Union took no count of the security dimension, or of what concern its actions could raise with its most prominent neighbor in the region, Russia. One should admit, though, that Russia itself was partly provoking such behavior from the EU. Over an extended period of time, at least from 1994 to 2003, the EU's enlargement was construed by some Russian experts as an alternative to NATO's unwelcome expansion (Danilov and De Spiegeleire, 1998; Póti, 2001, p. 147).

Generally, Russia considered the security issue from the perspective of traditional approaches to ensuring national security and parrying eventual risks and threats. But as soon as it acquired the necessary military and political resources, it firmly stated its position. Thus, the fundamental divergence-an essentially different vision of the regional security agenda-was gradually becoming more and more obvious. The EU and its leading states viewed regional security 


\section{Timofei V. Bordachev}

through the prism of extension of their sphere of influence and control by involving new countries in the "EU-centric" system, while Russia saw it from the standpoint of preventing potential threats to national security on the part of alliances and military blocs whose decisionmaking mechanism was beyond its purview.

The critical point in the EU-Russia relations in terms of security was the 2008 Georgia crisis, which had been largely provoked by the discussions over Georgia's and Ukraine's participation in an action plan for preparations to attain NATO membership. As early as 2009, the Russian government came forward with an initiative to hold a dialogue with the European Union on revising and strengthening the European security architecture. Specifically, it suggested reinforcing existing institutions (OSCE) and creating new formats of relations. The 2010 Mesenberg Initiative of Russia and Germany contemplated the possibility of setting up an EU-Russia Committee on Foreign and Security Policy at the ministerial level (Minister of Foreign Affairs S. Lavrov-High Representative C. Ashton). Eventually, the Mesenberg Initiative was swept under the carpet by the EU as unacceptable for a large group of Central and Eastern European states. (It should be noted that there are fundamental studies offering systemic approaches to the periodization of Russia-EU relations (Deak and Kuznetsov, 2019)).

Finally, the European Union responded to the Georgia crisis by just what it should not have done: in 2009 it adopted the "Eastern Partnership" policy directly aimed at tearing away from Russia western post-Soviet states which remained beyond the framework of the EU enlargement (Delcour, 2018). This policy included the signing of Enhanced Partnership Agreements which envisaged-in the optimal version-complete opening of those countries' markets for EU goods and approximation of the regulatory norms, without indicating this as a prerequisite for, or a step towards, their actual accession to the EU, as had been done for candidate countries in the 1990s. In Russia, this initiative was taken as a direct threat to regional stability and security - in the shared neighborhood with the EU—as it posed a serious challenge to former Soviet states. However, the European Union did not pay heed to Russia's rationale. The result was the start of 
the military-diplomatic crisis over Ukraine, which eventually brought the relations between Russia and the EU to their present state.

Not surprisingly, there was no progress towards a rapprochement of the partners' interests and actions, either in form or in content. As a result, in the middle of the current decade there emerged hostility in relations between Russia and leading European countries, which has gradually transformed into an ordered estrangement. At the same time, the necessary diplomatic politesse and economic projects critical for some EU states (like in the energy sphere where the U.S. can do anything but make Europeans give up cooperation with Russia) have been maintained and even invigorated (Tichý and Kratochvíl, 2014; Van der Meulen, 2009; Dimitrova, 2010). Yet there remains a fundamental complex question: Can Europe stop viewing Russia merely as an area of resource development? And if so, why would it do that? Also, can Russia give up looking at Europe as a potential asset within the framework of relations with more powerful players-the U.S. and China, whose magnitude inevitably poses a potential challenge to the very existence of the Russian civilization?

Russia has always been challenged by a complicated internal arrangement of modern Europe, where supranational and interstate elements are combined, with the latter prevailing, (Gehring, Urbanski and Oberthür, 2017). Despite the advanced level and large scale of integration, the European Union remains an association of sovereign states. The difference between them is the extent to which each of them can make its national interest an interest of the community. Therefore, the relations between Russia and Europe in the modern period have in fact become interstate relations, where EU supranational institutions play the role of intermediaries with limited rights (Nitoiu, 2014).

Throughout the entire history of relations between Russia and the European Union, they have been developing under substantial influence of external and internal factors, which have limited the ability of both partners to see these relations as self-important and strategic. The combination of these constraints made the parties unable to overcome the anarchic nature of these relations. Initially conceived as integrative-in nature and content-these relations 
inevitably degenerated into purely diplomatic. Their form and essence were chronically coming into contradiction with each other.

For both Russia and the European Union, cooperation and potential integration have always been not a vital necessity, without which it would be impossible to attain major goals of development, but an additional opportunity (which they could use or not use, or else use partially). Correspondingly, the parties regarded the benefits from cooperation as relative for themselves, rather than absolute, providing equal advantages for all, and thus, serving as a natural systemic factor.

The resulting disharmony generated numerous irritants and eventually made the parties unable to build a dialogue, even when peace and security were put in jeopardy. At present, the relations between Russia and Europe are developing in a basically new context largely determined by the so-called "rise of Asia." The leading Asian powers, above all India and China, are making their way to leading positions in world affairs. Their opinion and strategic culture, which for centuries remained peripheral and seen as optional by the international community, are becoming major factors in the remaking of world politics (Rafiq, 2018; Rössler, 2009).

One of the consequences of these tectonic shifts is the change of U.S. global strategy. What was presented to the world by the Trump administration as an extremal version reflects a profound public aspiration and a no less profound readiness of the American government to respond to it. The internal transformation of Europe and the prospect of a qualitative reform of the entire architecture of European integration are also becoming major factors of change (Lipman and Trenin, 2013). The elections to the European Parliament and an almost all-round success of right-wing forces in Europe indicate that the model created and developed in the previous 30-40 years has reached its limits and has to be changed. We are witnessing a general decline of the institutional component of international relations and an unbalancing of world politics. The structure of the international system is changing and at this point it is not clear what form it will take. The main features of this new structure will apparently depend on the outcome of the systemic U.S.China confrontation which has started in recent years. 
Today it is obvious that the choice between integration and diplomacy in Russia-Europe relations has been made in favor of the latter, that is, in favor of relations aimed at solving current issues and removing immediate threats, without any long-term planning and without a common vision of the future. But is it a tragedy or, at least, a drama from the point of view of the most pressing problems of development that history is setting for both parties? Many analysts, especially in Russia (since Europe is now much more preoccupied with its own problems), speak of mutual detachment or semi-detachment (Lukyanov and Miller, 2017). This is substantiated, above all, by the internal demand for change by each of the parties in the relations under review-a reform of the European integration and final shaping up of Russia as an integral constituent of the international system.

However, one should not forget that external structural factors will be exerting much bigger influence (and even pressure) on Russia and Europe than ever before. Therefore, an important question arises: What may be a third alternative to the ongoing detachment or integration impairing natural interests and possibilities of one of the parties? This alternative must be flexible enough to prevent the main threat of drawing Europe and Russia into a war, while at the same time ensure a gradual increase in the number of factors working towards a situation where the parties would give preference to absolute benefits from cooperation over relative ones.

\section{EVOLUTION OF RUSSIA-EUROPE RELATIONS AFTER 1991}

Of course, the relations between Russia and the European Union did not start from scratch. There had been a short but eventful history of recognition of the European Economic Community by the USSR and its allies during perestroika and the period of "new political thinking." On June 25, 1988, the USSR and the EEC signed a trade and cooperation agreement. Note that the agreement was concluded not between the COMECON and the EEC, but on a bilateral basis. The Soviet leadership did not think of the importance of the multilateral format of relations with the European Union, which theoretically could help extend the life of the Council for Mutual Economic 


\section{Timofei V. Bordachev}

Assistance and later facilitate a smoother and equal-right integration of the two European economic associations (Romano, 2014; Mueller, 2011). European associations, on their part, were quite satisfied with Moscow's approach, as dealing with each COMECON member-state enabled them to faster and more efficiently gear up for COMECON disintegration and admit its European member-states to the EEC one by one, and exclusively on the conditions set by Brussels and the leading European capitals (Verny and Vale, 1988). A Cooperation Agreement (an utterly framework one) between the EEC and the COMECON was signed just several months before the demise of the latter in 1989.

Simultaneously, there was more and more active talk about possible formation of a special model of relations on the vast expanse "from the Atlantic to Vladivostok" that would include Europe and Russia. Remarkably, these plans were never given serious expert examination, while literature going beyond political debates is very limited. One can suppose that possibilities for systemic and long-term cooperation between the USSR and the European Communities was from the very start limited, on the one hand, by the uncertain future of the USSR and, on the other hand, by the fact that European integration had entered a period of qualitative reforms, which resulted in the signing in 1991 of the Maastricht Treaty and the materialization of the European Union as we know it today.

The collapse of the USSR, which was followed by several dramatic events practically in all of its former republics, and the EU's simultaneous emergence in a new quality as a semi-economic and semipolitical association were also factors undermining any efforts to establish a systemic dialogue between the parties. The emergence of new independent states in the post-Soviet territory, three of which (Latvia, Lithuania, and Estonia) right away raised the question of accession to the European Union and NATO (in fact, even before gaining actual independence), made any attempts by the EU to establish systemic relations with the government of the collapsing superpower senseless.

At that time the EU was busy assimilating the Soviet legacy and incorporating its parts into a system of "concentric circles," in which Europe would play the role of the natural core. Importantly, it was 
then that a discussion was launched on the possibility of building up a strategic alliance of Russia and Europe. This discussion was incited and sustained mainly by Russia, which is quite understandable. The very meaning of strategic alliance suggested transition to an equitable model of relations, which in no way could fit into any of Europe's two visions of Russia: as an "apprentice" (once again over centuries) or as a "consolidating Other," with the strategic space between them planned to be taken by the $\mathrm{EU}$ in the course of its enlargement to the east (Lynch, 2004). An important controversial issue was the hypothetical probability of an alternative to such a course of events. The discussions over the speed and scale of the EU's enlargement to the east continued until the mid-1990s, but the move itself was never put in question.

Historically, Russia and the European Union became participants in international relations simultaneously, amid a radical change of the international system structure in the wake of the Cold War. After the breakup of the Soviet Union international relations entered a new, unique period of relatively incontestable leadership of one power, when the international system structure got most closely to a unipolar order marked by U.S. hegemony and privileged status of U.S. allies in Western Europe. Like any theoretically conceivable unipolar order, the U.S.'s relative hegemony in the 1990-first half of the 2000s did not suggest incorporation in the privileged group of any powers comparable to the hegemon in terms of military capability. In view of this, the participation of Russia in the G8 deserves separate scrutiny.

The new structure of international system was marked by abrupt weakening of the real authority of the UN and other international organizations, the start of debates on their reform, Western countries' desire to lead the decision-making process concerning major problems facing humankind, from intra-state conflicts to climate change, and a relatively weak role of non-Western growing centers of power, above all China. Russia and the European Union treated this international context from essentially different positions.

After the adoption of the Maastricht Treaty, the European Union set the goal of becoming a full-fledged and influential center of power. In the first half of the 1990s, the EU began to actively implement 


\section{Timofei V. Bordachev}

such large-scale projects as introduction of the euro in cash and noncash transactions, enlargement to the east and to the Mediterranean, and made attempts, albeit not very successful, to create common mechanisms in foreign and security policies. All these measures were supposed to make Europe able if not to act on equal terms with the U.S. in the world arena then at least to control its own periphery, have a say in global affairs, and even to compete with it in certain spheres, such as challenging the U.S. dollar in financial markets.

Implementation of this challenging task could have been considerably facilitated had Europe been prepared for strategic alliance with Russia. Even in its weakest position at the end of the 1990s, Russia, owing to its immense natural resources and military potential, could have increased Europe's military strategic and economic might several times over. However, this proved to be impossible. Europe continued to perceive Russia as a country too vast and historically alien to be painlessly integrated with an association of small and medium-sized states.

Association with Russia, even conceptually, posed a challenge to the U.S. might and the structure of all Western institutions, the most important of which was NATO (Luňák, 1999). Feverish attempts to make NATO useful after the end of the Cold War gave way to vigorous preparations for its eastward expansion already in the mid-1990s, and, after the events of the spring and summer of 1999 it became completely clear that NATO's main potential adversary in Europe was Russia, if not in the immediate future then in 10-15 years' perspective. Considering the chaos reigning in Russia in the 1990s, any serious talk that some hypothetical association with it could help Europe gain strategic sovereignty looked unfeasible, albeit far-seeing.

Russia was to adapt itself to the new reality and take into consideration the drastic setback in its capabilities. This was taking place at a time when there was no alternative to the West as a source of resources for development programs. The first Chinese initiative of genuinely international scale was put forward only in 2013, that is, twenty years after Russia had to decide on its positioning in the new world and integration in the international community. 
In that historic period Moscow faced a large-scale task of its international rehabilitation and, at the same time, protection of its basic national interests, above all its territorial integrity. The latter problem, or, more precisely, its consequence as the First Chechen war of 19941996, was one of the reasons for the delay in the ratification by the European Union of the 1994 Partnership and Cooperation Agreement between Russia, the EU and its member states. The Agreement came into force only in 1997, when the strategic lines of development of both Russia and Europe had been generally defined (Smith, 2014). Thus, the 1994 Agreement came not as a strategic manifesto but a technical document, and both parties perceived it exactly as such.

As for international rehabilitation of Russia, the priority was accession to the G7 and the WTO, where the U.S. had the decisive vote. Besides, up until the completion of its grand-scale enlargement in the 2000s, the European Union could not offer its partners, including vast Russia, any consistent agenda of cooperation and integration, even in terms of organization (Asmus, 2008). It was suggested that Russia should "work on itself' and make itself closer to European standardswithout any clear prospects of tangible economic (access to markets) or political/moral (rehabilitation as a global player) benefits for itself (unlike EU candidate countries).

In other words, in 1991-2001 Russia and Europe were solving the task of their global positioning on their own, the way they saw them. A closer analysis of these tasks shows that practically none of them required close cooperation or integration of the partners.

Thus, the dual nature of Russia-EU relations up until the beginning of the systemic crisis in 2014 was determined by the fact that none of the partners could perceive strategic rapprochement as an essential means of survival in the long term. The strategic deadlock was brought about by exactly this contradiction between the subjective desire to cooperate and the objective lack of necessity to do so in earnest in order to take into account the spheres of cooperation and the partners' interests while shaping their home and foreign policies. The partnership of Russia and the EU has never been a "partnership of necessity"; it has always remained a "partnership of choice" (Schmidt-Felzmann, 2016). 


\section{Timofei V. Bordachev}

Some renowned Russian political scientists even tried to apply to Russia the approach of the so-called "English School" in the IR theory, maintaining that the country stood a good chance of becoming part of the "international community", that is, the West (Trenin, 2002). Other scholars thought that the West should accept Russia as it was, and in so doing become stronger itself. None of these viewpoints took the upper hand. So, it looks inappropriate now to attribute the gradual deterioration of Russia-EU relations to the state of crisis just to the missteps made by the West. The reasons for such outcome are much more profound.

The question of how indicative the tactics of "joining Europe" was of Russia's strategic choice in favor of European integration "on any terms" (as was the case with Central and Eastern European countries) remains open. No doubt, during the darkest period of Russian history, in the decade of 1991-2001, only Europe could serve as a source of investment, technologies and development programs for Russia. However, the significance of the European Union for the country's strategic survival was next to none and, consequently, Russia was not ready to take European recipes in earnest.

The European integration project entered the 1990s with a completely different "baggage." The collapse of the socialist system in Eastern Europe was perceived not only as a challenge (the need to take in a multitude of Eastern Europeans), but also as an opportunity (the emergence of an unprecedented expanse of resource development), especially with regard to the human capital, which was historically, culturally, and religiously akin as no other would be. The formation of a united Europe, with its gigantic market and population of about 500 million, made it incontestably second in the world hierarchy. But incorporation of Russia into such a system on European terms was impossible. Moreover, Europe did not need it. With a population of half a billion, Europe did not need Russia in order to survive in the then calm global environment.

At most, one could expect Russia to slowly move towards a model similar to that of Ukraine and other countries of "Eastern neighborhood," a territory of unhurried resource development. Therefore, all negotiations on a new strategic Agreement, which Russia 
and Europe were engaged in starting from 2005, were based on the assumption that there was no strategic prospect, even a long-term one, of building an integral whole based on the two international entities. The most far-seeing observers aptly noted, however, that such a whole could in the long run become an international player comparable to China and the U.S. (Rössler, 2009).

Furthermore, both Russia and the EU, besides lacking strategic need in each other, soon got real alternatives. In fact, Europe already had such an alternative in the face of the U.S. As soon as the global financial crisis broke out, it became clear that Europeans would not hold out without the support from Washington and financial institutions controlled by it. Russia received a convincing alternative in terms of tactically needed resources and technologies from rising China. Nonetheless, like in the case of Europe, China did not and, apparently, will not become a partner without which Russia will not be able to survive.

In principle, the problem of existence or non-existence of an alternative is typical of any close cooperation between sovereign states. An ideal case is the European integration. ASEAN, MERCUSOR, and integration associations in the post-Soviet space are less spectacular examples. In all these cases, participation in an association does not provide the member countries with "absolute" benefits from integration, which in the long term are more important than any losses or acquisitions.

Russia and Europe will have to address, side by side, or even together, many challenges which the 21 st century has in store for them. Europe has failed, and will hardly be able, to create a politically integrated space capable of acting unitedly in the global arena. Russia will remain a country which can ensure its sovereignty and survival on its own, without support from allies. The crisis that started in the relations between Russia and Europe five years ago was largely the result of their insufficiently sound approach to the future of their bilateral relations. Today the EU and Russia continue to act within the same old paradigm, although it has outlived its usefulness. However, in the years to come Russian and European intellectuals will have a unique opportunity to 


\section{Timofei V. Bordachev}

look at the bilateral relations without reservation and discuss what these relations must be like in order to survive the troubled 21st-century world, in which we do not need each other too much.

This discussion must primarily focus on the attitude of Russia and Europe towards major regional security institutions and, in a lesser degree, development institutions. For Russia, the central issue concerning these institutions is their role as consolidated and inclusive associations, where the voice of Moscow will be heeded and be able to influence the pan-European agenda. Besides, Russia views institutions like the OSCE as a possible alternative to NATO and, later possibly, to the European Union. Last but not least, there remain strategic global concerns of Russia as the legal successor of the USSR (Larrabee, 2003).

The European Union, on its part, has been regarding the pan-European institutions from the perspective of acting more independently in addressing regional and global matters and, which is no less important, in strengthening the unanimity within the union on issues of foreign policy and security strategy. For the European Union, such institutions as the Council of Europe or the OSCE have always been important not per se, but as instruments of promoting its foreign-policy agenda. It is not accidental that in all known schemes of organization of the pan-European space both these entities have always been presented and positioned only in reference to their closeness and connection to the core, the European Union. Importantly, all EU countries must act in the Council of Europe or the OSCE from a uniform, pre-agreed position.

As a result, Russia acted in the Council of Europe and the OSCE as an individual country, while the EU did so as a disciplined bloc, which predetermined the basic difference in their approaches, strategies, and tactics. This particular circumstance made contradictions between the two parties inevitable and gradually proved ruinous for the capacity of the OSCE and the European Council. Little by little, both these institutions have turned into a kind of "battlefield" for Russia's and Europe's diplomacy, which as early as the second half of the 2000s largely thwarted their activity (Smith, 2014). However, this did not rule out the parties' consent on individual tactical or technical issues. 
Overtheperiod of 1991-2008, relationsbetween Russiaand theEuropean Union went through the stages of enthusiasm, disappointment, new enthusiasm, and eventually, at the end of the 2000s, plunged into stagnation (Casier, 2016). The last attempt to revitalize them was the so-called "Partnership for Modernization" initiative which the parties put forward in 2009. This initiative was the EU's response to the debates over the necessity to modernize the Russian economy and society, which gained momentum under President Medvedev, and suggested substantial support from the European Union to any modernization initiatives of the Russian government. However, this initiative proved dead-born, as it immediately bumped into the partners' different visions of modernization as such. For Russia, the question was, above all, renovation of the scientific and technological base of its economy, whereas for Europe the case was reorganization of Russian institutions and of its entire sociopolitical system.

An additional irritant was the considerable number of new representatives in the European Commission from Central and Eastern European countries which had just joined the EU. By the end of the 2010s, the talks on the "Partnership for Modernization" had faded away, and negotiations on a new Russia-EU Strategic Agreement were in fact suspended in December 2010. All discussions on modernization were eventually buried by the crisis which broke out in the eurozone and by the complication of political relations in late 2011-early 2012 . In addition, both Russia and the European Union had to address more serious challenges related to global changes.

\section{RUSSIA AND EUROPE FACING EVER NEW CHALLENGES}

The structural transformation of international relations, which started after the U.S. and its allies had failed to build a unipolar world order, posed new challenges to Russia and the European Union, and each of them has been addressing them in line with its own structural specifics.

At the end of the 2000s, the European Union set a course for smooth involvement of post-Soviet states into the sphere of its influence through a new system of privileged trade and economic partnership 


\section{Timofei V. Bordachev}

agreements. Russia, on its part, took steps to enhance its global reach by getting involved in the conflict in Syria and, simultaneously, by setting up institutions for cooperation and integration in the post-Soviet space, such as the Eurasian Economic Union (EAEU) (Korzhengulova, Shkvarya and Melanyina, 2017).

The confrontation of Russia and the EU over Ukraine was exactly the result of their efforts to address challenges of global dimension (Haukkala, 2015). Both parties proposed to Ukraine practically identical formats of cooperation based on integration of regulatory mechanisms and practices. The Ukrainian elite and public found themselves facing a stark choice, which led to a logjam of contradictions in society and the political system and eventually ended in a political upheaval in the winter of 2013-2014, followed by external interference and the country's plunging into a military-political crisis.

However, the main issue for the present analysis is not the dramatic events in Ukraine, but its position in the context of relations between Russia and the European Union. In this sense, the clash of the interests of the players around a particular geopolitical entity is nothing more than a derivative of Russia's and Europe's efforts to find their own place in the changing world and instruments to use for such global selfpositioning (Urnov, 2014; Gehring, Urbanski and Oberthür, 2017). Had Russia failed to turn to more structured forms of cooperation with its neighbors (EAEU) in the early 2010s, the Ukrainian authorities would have been able to comfortably sign an enhanced Partnership Agreement with the EU, and at the same time continue to develop relations with Russia. However, in 2013 the previously used patterns were no longer possible to implement.

It is noteworthy that relations between Russia and China, after the Belt and Road Initiative was launched by Beijing in 2013, have been developing according to an essentially different scenario. After some period of pondering, Moscow welcomed this initiative, and in May 2015 a Joint Statement of the Russian Federation and the People's Republic of China on Conjunction of the EAEU and the Silk Road Economic Belt was signed. In May 2018, this statement was furthered by signing a relevant agreement between the EAEU and the PRC in Astana. 
However, if we look back at the beginning of the 2010s, we will see that, just like Russia, the European Union, having lost all hope of becoming a full-fledged global player, was forced to organize in a more systemic way-on the reflective level-its immediate neighborhood where Ukraine was undoubtedly a key element. For the sake of controlling this element, i.e. solving the issue of its own self-positioning in the global and regional arena, the EU was prepared to sacrifice its relations with Russia, which it had been calling "truly strategic" (the Common Strategy of the European Union on Russia, 1999).

Let us point out that the European Union's actions which entailed a qualitative change in Russia-EU relations were not the result of some preliminary plan. In full accordance with the systemic theory of international relations, they were nothing more than a reflex response to the changes in the outside environment-a response, to which Russia, on its part, retaliated in kind.

In no smaller part, the crisis around Ukraine was ignited by the changes within the European Union (Maass, 2016). During the period of 2008-2015, European integration was faced with two major crises: the crisis of the eurozone and the migration crisis (Nyquist and Cernea, 2018; Braghiroli and Makarychev, 2018). Among the consequences of these crises were the termination of the European integration model created in the first half of the 1980s and the start of a fundamental restructuring of the entire EU political system, both at the national and, perhaps, at the pan-European levels. Measures taken to cope with the non-payment crisis in the eurozone resulted in a situation where the economic policy of the whole group of EU member-states was actually put under control of the European Central Bank and EU inter-governmental institutions. These measures have upset the entire historically formed model of European integration development.

Historically, Europe has always been confronted with the choice between two scenarios of unification. Let us designate them "unity according to Rousseau" and "unity according to Hobbes." The first one suggests a voluntary unity of European countries on issues that do not infringe on their sovereign rights. It was precisely this model that from the very start was taken as the basis of European integration 


\section{Timofei V. Bordachev}

and over the past 10-15 years has been subject to serious distortions. The second model, "according to Hobbes," is an imperial model with a strong common center. Attempts to build such a center were made, for instance, by Napoleon and Hitler. The modern European establishment was quite comfortable under the wing of European bureaucracy and practices dictated by it, notwithstanding the fact that those practices were either turning into factors limiting the development opportunities for a large group of EU member-states, or creating a situation threatening the physical security of their citizens.

A telling illustration of such state of affairs was the situation around the liquidation of the consequences of the migration crisis, which unfolded in 2015-2016. As it happened, several million refugees from the Middle East and North Africa escaping massive turmoil on their native soil were distributed quite unevenly across Europe. The greater part of the expatriates were accepted by well-off Germany, but less prosperous countries of Southern Europe also had to bear the burden of the inflow of migrants.

State and government leaders of EU countries failed to find a solution which could lead to a reform of the General Policy on Refuges. Instead, they made a separate agreement with Turkey, offering it monetary compensation for retaining migrants in its territory. Remarkably, the rule, stipulating that processing refugees' claims is the responsibility of the country whose soil they first stepped on, remains unchanged. The migration crisis triggered a drastic upsurge of right-wing sentiments, which resulted in the rightist forces' coming to power in Italy and impressive success in the elections to the European Parliament in May 2019.

All these political headwinds have placed in jeopardy the development paradigm of European integration, the way it was conceived in the first half of the 1980s. The entire political system of the EU has entered a period of profound restructuring, which cannot but influence its relations with Russia. All the more so as this is happening amid increasingly active and expanding geo-economic and geopolitical processes in Asia and Eurasia. Russia got involved in these processes from the very start and is now acting not just as a 
traditional guarantor of security in Central Asia but also as a source of new concepts for the future of Eurasia in general (Korzhengulova, Shkvarya and Melanyina, 2017).

Conceptualization of the idea of Greater Eurasia, Eurasian economic integration, and the transformation of the European Union open up new opportunities for re-building relations between Russia and the EU by abandoning past practices (typical of the 1991-2019 period). Europe, which is currently undergoing internal restructuring, will inevitably face the challenges of new Eurasian processes and will have to address them in the conditions of increasingly complicated relations with its traditional partner, the U.S. The response may be either self-isolation and limited economic cooperation with Eurasian partners or, on the contrary, more openness.

The tectonic shift was triggered by the Belt and Road Initiative, which China launched in 2013 and which Russia welcomed in 2015 in a joint Statement on Conjunction of the EAEU and the SREB. Today, the Belt and Road Initiative has become a full-fledged large-scale project of joint economic development of its participating states. In the new historical conditions, a return to the practices which prevailed in relations between Russia and Europe before the 2014 crisis, is impossible and, apparently, neither of the parties views it as expedient. However, in the mid-term perspective they may build a new model of relations based on objective assessment of systemic resources and restrictions.

Summarizing the above, I can make several conclusions and suppositions.

Firstly, in strict accordance with the postulates of the systemic theory of international relations, the European Union and Russia have been building their foreign policies in response to the challenges of the changing international environment.

Secondly, integration and strategic partnership have never been vital either to Russia or to the EU (but especially the EU) for attaining major development goals in the regional and global arena. 


\section{Timofei V. Bordachev}

Thirdly, the tasks which Russia and the EU have been solving in the context of their regional and global positioning often came into collision with each other, giving rise to conflicts.

Fourthly, the approaches of Russia and the European Union to ensuring regional security have been and still are essentially different. This circumstance was largely the reason why their relations were not frozen at the stage of stagnation (which occurred as early as 2010) but moved into a phase of military-diplomatic crisis.

Fifthly, the dramatic changes in the international environment in recent years will not let Russia and the European Union solve the tasks of their internal development and survival without entering into direct constructive cooperation.

Lastly, it is necessary to try to create flexible diplomatic mechanisms to harmonize the interests of Russia and Europe, which will enable both parties to solve their development tasks without collisions and, furthermore, use the opportunities of joint development opening up in Greater Eurasia.

\section{References}

Asmus, R., 2008. Europe's Eastern Promise: Rethinking NATO and EU Enlargement. Foreign Affairs, 87(1), pp. 95-106. Available at: http://www.jstor. org/stable/20020270 [Accessed 28 May 2019].

Baranovsky, V. and Utkin, S., 2012. Europe as Seen from Russia. Perspectives, 20(2), pp. 63-81. Available at: http://www.jstor.org/stable/23616131 [Accessed 28 May 2019].

Braghiroli, S. and Makarychev, A., 2018. Redefining Europe: Russia and the 2015 Refugee Crisis. Geopolitics, 23:4, pp. 823-848.

Casier, T., 2013. The EU-Russia Strategic Partnership: Challenging the Normative Argument. Europe-Asia Studies, 65:7, pp. 1377-1395.

Casier, T., 2016. From Logic of Competition to Conflict: Understanding the Dynamics of EU-Russia Relations. Contemporary Politics, 22:3, pp. 376-394. Available at: https://www.tandfonline.com/doi/abs/10.1080/13569775.2016.12 01311 [Accessed 28 May 2019]. 
Danilov, D. and De Spiegeleire, S., 1998. From Decoupling to Recoupling: A New Security Relationship between Russia and Western Europe? Paris: Institute for Security Studies of WEU.

Deak, A. and Kuznetsov, A., 2019. Relational Locomotive or Apple of Discord? Bilateral Perceptions of the Economic Cooperation. Journal of Contemporary European Studies, 27(3), 159-170, DOI: 10.1080/14782804.2019.1566118

Delcour, L., 2018. Dealing with the Elephant in the Room: The EU, Its 'Eastern neighbourhood' and Russia. Contemporary Politics, 24:1, pp. 14-29.

Dimitrova, I., 2010. EU-Russia Energy Diplomacy: 2010 and Beyond? Connections, 9(4), pp. 1-16. Available at: http://www.jstor.org/stable/26326221 [Accessed 28 May 2019].

EU Collective Strategy, 1999. Kollektivnaya strategia ES po otnosheniyu k Rossii [EU Collective Strategy towards Russia]. Köln Available at: https://mgimo.ru/ files2/y11_2013/243404/4.3.collective_eu_strategy.htm

Gehring, T., Urbanski, K. and Oberthür, S., 2017. The European Union as an Inadvertent Great Power: EU Actorness and the Ukraine Crisis. JCMS, Vol. 55, No. 4, pp. 727-743.

Haukkala, H., 2009. Lost in Translation. Why the EU Has Failed to Influence Russia's Development. Europe-Asia Studies, 61:10, pp. 1757-1775.

Haukkala, H., 2010. The EU-Russia Strategic Partnership: The Limits of PostSovereignty in International Relations. Routledge. 270 p. Available at: https:// www.taylorfrancis.com/books/9781135150136 [Accessed 28 May 2019].

Haukkala, H., 2015. From Cooperative to Contested Europe? The Conflict in Ukraine as a Culmination of a Long-Term Crisis in EU-Russia Relations. Journal of Contemporary European Studies, 23:1, pp. 25-40.

Kononenko, V., 2009. Russia: Strategic Loneliness. The World Today, 65(7), pp. 23-24. Available at: http://www.jstor.org/stable/41548924 [Accessed 28 May 2019].

Korzhengulova, A., Shkvarya, L. and Melanyina, M., 2017. The EU-Russia Conceptual Interaction in the Eurasian Space in the Context of Western Sanctions. Central Asia \& the Caucasus (14046091), [s. 1.], Vol. 18, No. 1, pp. 7-14.

Larrabee, F., 2003. NATO’s Eastern Agenda in a New Strategic Era. Santa Monica, CA; Arlington, VA; Pittsburgh, PA: RAND Corporation, Chapter 5 Whither Russia?, pp. 115-158. Available at: http://www.jstor.org/stable/10.7249/ mr1744af.12 [Accessed 28 May 2019]. 


\section{Timofei V. Bordachev}

Leonard, M. and Popescu, N., 2007. A Power-Audit of EU-Russia Relations. European Council on Foreign Relations [online]. Available at: https://www.ecfr. eu/publications/summary/a_power_audit_of_eu_russia_relations [Accessed 28 May 2019].

Lipman, M. and Trenin, D., 2013. The End of an Era in EU-Russia Relations. Carnegie Moscow Center [online]. Available at: https://carnegie.ru/2013/05/30/ end-of-era-in-eu-russia-relations-pub-51950 [Accessed 28 May 2019].

Lukyanov, F. and Miller, A., 2017. Sderzhannost' vmesto naporistosti [Detachment instead of Aggressiveness]. Rossia v global'noi politike, No. 4. Available at: https://globalaffairs.ru/number/Sderzhannost-vmesto-naporistosti-18927 Luňák, P., 1999. Chasing a Maverick: The West's Russia Policy. Perspectives, (13), pp. 105-117. Available at: http://www.jstor.org/stable/23615946 [Accessed 28 May 2019].

Lynch, D., 2004. Russia's strategic partnership with Europe. Washington Quarterly, 27:2, pp. 99-118.

Maass, A.-S., 2016. EU-Russia Relations, 1999-2015: From Courtship to Confrontation. Routledge Contemporary Russia and Eastern Europe Series. Available at: https://www.crcpress.com/EU-Russia-Relations-1999-2015From-Courtship-to-Confrontation/Maass/p/book/9780815356141 [Accessed 28 May 2019].

Mueller, W., 2011. Recognition in Return for Détente? Journal of Cold War Studies, Vol. 13, No. 4, pp. 79-100.

Neumann, I.B., 1995. Russia and the Idea of Europe: A Study in Identity and International Relations. Routledge. $242 \mathrm{p}$.

Nitoiu, C., 2014. EU-Russia Relations: Between Conflict and Cooperation. International Politics, 51, pp. 234-253.

Nyquist,J.R.andCernea,A.M.,2018. RussianStrategyandEurope'sRefugeeCrisis. Center for Security Policy, 5. Available at: https://www.centerforsecuritypolicy. org/wp-content/uploads/2018/05/Russia_Refugee_05-28-18.pdf [Accessed 28 May 2019].

Póti, L., 2002. Putin's European Policy. In: Bugajski, Janusz, ed. Toward an Understanding of Russia: New European Perspectives, pp.135-151.

Rafiq, R. F., 2018. Eurasia and Future Geo-Strategic Calculus. Journal of Defense Resources Management, 9(1), pp. 64-75. Available at: https://search.proquest. com/docview/2178518291?accountid=45451 [Accessed 28 May 2019]. 
Roberts, C. A., 2007. Russia and the European Union: The Sources and Limits of Special Relationships. The Strategic Studies Institute.

Romano, A., 2014. Untying Cold War Knots: The EEC and Eastern Europe in the Long 1970s. Cold War History, 14:2, pp. 153-173.

Romanova, T. A., 2016. Russia and Europe: Somewhat Different, Somewhat the Same? RIAC. Policy Brief, No. 5, July. Available at: https://russiancouncil.ru/ common/upload/Russia-Europe-Policybrief5-en.pdf [Accessed 28 May 2019].

Rössler, J., 2009. Eurasia: Re-Emergence of Two World Regions. Asia Europe Journal, 7, pp. 313-326.

Schmidt-Felzmann, A., 2016. The Breakdown of the EU's Strategic partnership with Russia: From Strategic Patience towards a Strategic Failure. Cambridge Review of International Affairs, 29:1, pp. 99-127.

Shillinglaw, T., 1978. Cooperation Between CMEA and EEC. The International Lawyer, Vol. 12, No. 3, pp. 677-679.

Smith, H., 2014. Russia as a Great Power: Status Inconsistency and the Two Chechen Wars. Communist and Post-Communist Studies, Vol. 47, No 3-4, pp. 355-363.

Tichý, L. and Kratochvíl, P., 2014. The EU-Russia Energy Relations under the Prism of the Political Discourse. Perspectives, 22(1), pp. 5-32. Available at: http://www.jstor.org/stable/24624579 [Accessed 28 May 2019].

Trenin, D.V., 2002. Konets Evrazii: Rossiya na granitse mezhdu geopolitikoì $i$ globalizatsiei [The End of Eurasia: Russia between Geopolitics and Globalization]. Moscow.

Urnov, M., 2014. 'Greatpowerness' as the Key Element of Russian SelfConsciousness under Erosion. Communist and Post-Communist Studies, Vol. 47, No. 3-4, pp. 305-322.

Van der Meulen, E., 2009. Gas Supply and EU-Russia Relations. Europe-Asia Studies, 61(5), pp. 833-856. Available at: http://www.jstor.org/stable/27752304 [Accessed 28 May 2019].

Verny, S. and Vale, M., 1988. The EEC and CMEA: The Problem of Mutual Recognition. Soviet and Eastern European Foreign Trade, Vol. 24, No. 2, pp. 6-25. White, S., Light, M. and McAllister, I., 2005. Russia and the West: Is there a values gap? International Politics, 42(3), pp. 314-333. 